\title{
Sewing transnational textures of labour regulation: towards an integrative perspective
}

\author{
Ludger Pries $\mathbb{i}$
}

Received: 9 March 2020 / Accepted: 4 May 2020 / Published online: 20 May 2020

(C) The Author(s). 2020 Open Access This article is licensed under a Creative Commons Attribution 4.0 International License, which permits use, sharing, adaptation, distribution and reproduction in any medium or format, as long as you give appropriate credit to the original author(s) and the source, provide a link to the Creative Commons licence, and indicate if changes were made. The images or other third party material in this article are included in the article's Creative Commons licence, unless indicated otherwise in a credit line to the material. If material is not included in the article's Creative Commons licence and your intended use is not permitted by statutory regulation or exceeds the permitted use, you will need to obtain permission directly from the copyright holder. To view a copy of this licence, visit http://creativecommons.org/licenses/by/4.0/.

Abstract Labour regulation is often approached either by methodological nationalism or methodological globalism. Main arguments are that labour and its regulation are increasingly dis-embedded and commodified. As an alternative framing we propose a (neo-)institutionalist multi-level and multi-actors approach. Based on literature review and own studies we argue that there is empirical evidence of transnational labour regulation combining different logics of action and institutional contexts. Taking the example of the Bangladesh Accord on Fire and Building Safety, we demonstrate the multi-level, multi-dimensional institutional settings and sketch out basic elements of an integrative perspective on sewing transnational textures of labour regulation.

Key terms Labour regulation, globalization, transnationalization, Bangladesh Accord, neo-institutionalism, multi-level multi-actor approach.

\section{Introduction}

In light of the actual degree of global and transnational social relations and interchanges of goods, capital, information, cognitive maps, and persons, the mechanisms of collective cross-border labour regulation remain considerably weak and 'underdeveloped.' Either by global value chains or by Multinational Companies (MNC), either by cross-

\section{Pries $(\bowtie)$}

Fakultät für Sozialwissenschaft - Fach 145, Raum GD E 1/313, Ruhr-Universität Bochum, Universitätsstr, 150, 44780 Bochum, Germany

e-mail: ludger.pries@rub.de 
border labour mobility or by the simple threat of transferring production and employment - the local conditions of work, employment and participation of workers are entangled worldwide. In contrast, labour regulation seems to be focused at the national or even local level. A frequently repeated argument is that global capitalism could be characterized by a singular trend towards marketization and economization. Many social scientists now predict a global overall tendency to increase 'commodification' of labour and in general to extricate the economy from its societal entanglements.

Referring to Karl Polanyi's notion of an institutional re-embedding of markets after World War II, Burawoy (2010): 307 claimed that this transformation was only short-lived and was followed by a new wave of market fundamentalism: "The reembedding of markets in the North, during the post-war period, was costly for capital, which responded with an offensive against labour, the environment and money, all in the endless pursuit of profit." He concludes, "We can call it the era of globalization in which the commodification of labour, money and nature labour migration, finance capital as well as environmental degradation - for the first time takes on a truly transnational character that is often outside the control of the state" (Burawoy 2010: 311). Following this line of argument and concerning labour regulation, a frequent lament could be summarized as follows: capital is increasingly global; unions as workers' representatives remain national; work and employment are local—and the overall situation of labour regulation is fatal.

But is this great narrative scientifically solid? Are global marketization and economization actually the only and universal trends? Doesn't the Trump administration in the USA demonstrate the power of state policy and politicization? Isn't the economy in China strongly embedded in political party and state structures that control and define the market logics? Couldn't we argue the same for Russia? Is there a universal trend of global marketization, or could we observe contradictory tendencies of globalization, regionalization, renationalization, and relocalization of markets and economies (Bugra and Agartan 2007)? Doesn't, for example, the Bangladesh Accord on Fire and Building Safety from May 2013 reflect the possibility of a certain re-embedding of global value chains in frameworks of negotiated and controlled legally binding agreements and corporate social responsibility (CSR) activities (Tighe 2014)?

The main argument strengthened in the following is that, referring to labour regulation and looking through institutionalist glasses, we identify (1) innovative and complex mechanisms of transnational, multi-sited collective regulation of work, employment and participation and (2) social institutions beyond the simple market-states-hierarchies logic. In spite of single-factor approaches such as global marketization and commodification or the universal dis-embedding of national economies and markets, we need conceptual frameworks that combine different institutional forces and tendencies. Market fundamentalism could be a one-sided ideology of economic actors, but it could also be an inadequate platform for social scientists. One alternative approach would be "varieties of capitalism" (Hall and Soskice 2001). Nevertheless, this is not much different from opposing only two models of economies (marketled vs. state-led), and it tends toward the fallacy of "methodological nationalism" (Wimmer and Schiller 2002). 
Another option could be the neo-institutionalist approach of world polity. According to this, against the weaknesses of national institutions global regulations need to be institutionalized in a regulative, normative, and cognitive manner (Scott 2001). This requires "institutional work" (Lawrence and Suddaby 2006). Nevertheless, this must not lead to a homogeneous and coherent "world order" (Meyer et al. 1997) but rather could take the form of different emerging and flexible entanglements of transnational labour regulation. As characterized by Besio and Meyer (2015): 237, "Instead of looking for an encompassing, stable order as an explanation for this stability, we claim that modern society has developed ways of mediating heterogeneous logics by generating fragmented and temporary orders."

Taking and differentiating these approaches, and based on a secondary analysis of studies and literature we argue that there is actually much empirical evidence of transnational labour regulation that combines quite different logics of action and institutional contexts (section 1). Nevertheless, these transnational mechanisms do not tend to an integrated world polity as institutionalized global governance. Taking the example of the Bangladesh Accord on Fire and Building Safety, we will demonstrate the multilevel and multidimensional institutional settings of transnational labour regulation (section 2). Between the Scylla of methodological nationalism and the Charybdis of methodological globalism, of economic determinism and activist voluntarism, this opens opportunities for an integrative perspective on sewing transnational textures of labour regulation (section 3).

\section{Results: towards a transnational approach to labour regulation}

Although considerable mechanisms exist for the cross-border regulation of work, employment, and participation relations, these aspects are traditionally analysed separately and in the tradition of methodological nationalism. Nevertheless, their actual functioning, effectiveness, and reach can be adequately assessed only when analysed in terms of their transnational entanglements and multidimensional interactions. Hassel (2008): 233 describes "the emergence of a new set of global labour governance by establishing a global labour standards regime." She reasons why MNC with stronger labour standards could be interested in their proliferation, presents a multitude of different initiatives and states (ibid: 244): "Over the last 20 years, the debate of labour standards moved from regulation by ILO convention to codes of conducts, from governments to multinational firms, from centralized approaches to decentralized settings." Tsogas (2009) proposed a model of international labour regulation differentiating hard and soft law and four different types of "trade relations" (unilateral, bilateral, regional, and multilateral). But this approach does not include the crucial dimension of actors involved. For instance, Tsogas includes the mechanism of Framework Agreements (IFA) as "bilateral" and puts it at the level of companies. But, as will be shown in this section, IFA are not bilateral in the sense of bi-national trade treaties (ibid: 79). IFA could include national unions in different countries, but also other types of workers' representative bodies like works councils (Dehnen 2013). As Tsogas (2009): 79 underlines, his 
model "adopts an open-ended, global trade perspective, rather than a more restrictive domestic labour law approach."

Considering the dynamics and debates in the field of transnational labour regulation at the beginning of the third decade of the twenty-first century, we will include relevant innovative mechanisms that go far beyond trade regulations and core labour standards, such as including labour aspects in labels, monitoring, certifications, as public campaigns and social movements. In what follows we will outline seven different types of international labour regulations that are relevant to the context of the transnationalization of work. These types of labour regulation differ with respect to their time of origin, the main subject of the regulation (thematic scope), their spatiotemporal scope, their implementation and control mechanisms, and the relevant groups of actors involved (see Table 1). In the light of transnational labour regulation, each of these mechanisms has strong limitations if analysed separately, but put in a broader transnational texture with other mechanisms of labour regulation, they could prove to be effective.

Probably the oldest strategy of cross-border (in this case, even global) labour market regulation is based on labour standards as defined and developed by the ILO ${ }^{1}$. Meanwhile, some 200 conventions have been adopted covering almost all aspects of labour regulation. In addition to this wide range of regulatory content, another feature characteristic of this strategy is that these conventions, negotiated with the participation of national employers' and trade unions' representatives, claim validity for all signatory states. As mentioned in the scientific literature, the most important shortcoming of this practice is the lack of effective monitoring and enforcement mechanisms.

A second type of regulation includes the provisions of other international organizations, such as the World Bank or the World Trade Organization (WTO). These provisions relate to aspects of employment and often refer to the aforementioned ILO conventions but are much more specific. Even though they have a farreaching effect in terms of space, such regulations are usually not supported by any strong control resources. The main actors here are the states affiliated with the United Nations and other international organizations. ${ }^{2}$

An example of the third type of transnational labour regulation is the European Works Council (EWC). In the 1980s, the corresponding EU Directive was established including negotiations with the social partners of employers' and workers' organizations. Although the EWC's powers are less far-reaching than those of German Works Councils, they do offer considerable information and consultation opportunities in multinational corporations (MNC) at the EU level. Another example of this type of 'supranational' employment-related regulation is the social dialogue between the European social partners and the complaint mechanisms under the

\footnotetext{
${ }^{1}$ For the first labour standard set by the International Labour Office (ILO) in 1906 see ILO 2001: $33 \mathrm{f}$. For scientific research and debates see e.g. Alston 2004; Hassel 2008; ILO (International Labour Office) 2009; Reynaud 2018; the current state of ratifications is listed under https:/www.ilo.org/dyn/normlex/ en/.

${ }^{2}$ Due to stagnation or crisis of multilateralism in general, this mechanism is challenged in its significance, see Bakvis and McCoy 2008; http://ec.europa.eu/trade/policy/eu-and-wto/dohadevelopment-agenda/; https://www.wto.org/english/res_e/reser_e/ersd201407_e.htm.
} 
Table 1 Types and characteristics of transnational labour regulation

\begin{tabular}{|c|c|c|c|c|c|c|}
\hline \multirow{2}{*}{$\begin{array}{l}\text { Type of } \\
\text { Regulation }\end{array}$} & \multicolumn{6}{|c|}{ Crucial Characteristics } \\
\hline & $\begin{array}{l}\text { Time of } \\
\text { origin }\end{array}$ & $\begin{array}{l}\text { Thematic } \\
\text { scope }\end{array}$ & $\begin{array}{l}\text { Spatial } \\
\text { scope }\end{array}$ & $\begin{array}{l}\text { Strength of } \\
\text { control }\end{array}$ & $\begin{array}{l}\text { Main actor } \\
\text { groups }\end{array}$ & Example \\
\hline $\begin{array}{l}\text { Global } \\
\text { minimum } \\
\text { standards }\end{array}$ & $1910 \mathrm{~s}$ & Broad & Global & Weak & $\begin{array}{l}\text { States, social } \\
\text { partners }\end{array}$ & $\begin{array}{l}\text { ILO core } \\
\text { conventions }\end{array}$ \\
\hline $\begin{array}{l}\text { Other relevant } \\
\text { international } \\
\text { norms }\end{array}$ & $1990 \mathrm{~s}$ & Narrow & $\begin{array}{l}\text { Global to } \\
\text { macro- } \\
\text { regional }\end{array}$ & Weak & States & $\begin{array}{l}\text { Labour-related } \\
\text { norms of World } \\
\text { Bank }\end{array}$ \\
\hline $\begin{array}{l}\text { Supranational } \\
\text { labour } \\
\text { regulation }\end{array}$ & $1980 \mathrm{~s}$ & Broad & $\begin{array}{l}\text { Macro- } \\
\text { regional }\end{array}$ & Strong & $\begin{array}{l}\text { States, social } \\
\text { partners, NGOs }\end{array}$ & $\begin{array}{l}\text { European } \\
\text { Works Council } \\
\text { (EWC) }\end{array}$ \\
\hline $\begin{array}{l}\text { Company- } \\
\text { related } \\
\text { declarations }\end{array}$ & $1990 \mathrm{~s}$ & Intermediate & $\begin{array}{l}\text { Global to } \\
\text { consortium- } \\
\text { related }\end{array}$ & Moderate & $\begin{array}{l}\text { Companies, } \\
\text { unions }\end{array}$ & $\begin{array}{l}\text { International } \\
\text { Framework } \\
\text { Agreements }\end{array}$ \\
\hline $\begin{array}{l}\text { Labels, } \\
\text { monitoring, } \\
\text { certifications }\end{array}$ & $1990 \mathrm{~s}$ & Broad & $\begin{array}{l}\text { Global to } \\
\text { local }\end{array}$ & Strong & $\begin{array}{l}\text { Experts, NGOs, } \\
\text { business } \\
\text { organizations }\end{array}$ & Fair trade \\
\hline $\begin{array}{l}\text { Public } \\
\text { campaigns, } \\
\text { social movements }\end{array}$ & $\begin{array}{l}\text { 1960s, } \\
\text { then } \\
1990 \mathrm{~s}\end{array}$ & Broad & $\begin{array}{l}\text { Global to } \\
\text { local }\end{array}$ & Medium & $\begin{array}{l}\text { NGOs, the } \\
\text { media, the } \\
\text { public }\end{array}$ & $\begin{array}{l}\text { Clean Clothes } \\
\text { Campaign }\end{array}$ \\
\hline $\begin{array}{l}\text { Supra/ } \\
\text { transnational } \\
\text { governance }\end{array}$ & $\begin{array}{l}\text { Twenty- } \\
\text { first } \\
\text { century }\end{array}$ & Broad & $\begin{array}{l}\text { Global to } \\
\text { macro- } \\
\text { regional }\end{array}$ & Strong & $\begin{array}{l}\text { States, social } \\
\text { partners, NGOs, } \\
\text { MNC }\end{array}$ & $\begin{array}{l}\text { OECD } \\
\text { Multinational } \\
\text { Guidelines }\end{array}$ \\
\hline
\end{tabular}

Source: Author's own elaboration

NAFTA Subsidiary Agreements (the North American Agreement on Labor Cooperation [NAALC] $)^{3}$.

The fourth type of labour regulation, in contrast, is the voluntary declaration of companies to adhere to certain work and employment standards and to the socalled International Framework Agreements (IFA), which provides for significantly smaller implementation mechanisms. Companies are the exclusive actors relevant to this type of regulation, although in the case of the IFA, the corresponding sectoral International Trade Union Confederations (now reorganized as Global Union Federations [GUF]) are involved as well. Here we see the lack of a legal or institutional anchorage as a relevant problem, meaning that no mechanisms of enforcement are included in these measures themselves ${ }^{4}$.

The fifth type of cross-border labour regulation comprises monitoring, certification, and labelling systems. The 'fair trade' label, for example, protects the producers of such products by monitoring certain fair trade relations and minimum labour standards, and the producers correspondingly agree to regular audits to

\footnotetext{
${ }^{3}$ For EWC, see e.g. Meardi 2004; Hertwig et al. 2010; Pulignano 2017; Hann et al. 2017; Hauser-Ditz et al. 2016; for Social Dialogue see e.g. https://www.eceg.org/what-we-do/social-dialogue/; for NAALC see e.g. Dombois et al. 2003.

${ }^{4}$ For IFA and GUF see e.g. Riisgaard 2005; Müller et al. 2008; Croucher and Cotton 2009; Dehnen and Pries 2014; Hadwiger 2015.
} 
comply with these standards. This type of regulation is characterized by the cooperation of a variety of different actors: producers, trading and selling companies, and expert organizations involved in independent monitoring or certification. Relatively strong control resources are combined here with variable topics to be regulated and a range that is spatially oriented to worldwide supply chains ${ }^{5}$.

The sixth type of transnational labour regulation involves public campaigns and social movements, in which international NGOs, the media, and the public play a significant role as control resources. In the Bangladesh Accord mentioned earlier, the years of preparation for the Clean Clothes Campaign (CCC), for example, were very important for creating public pressure on textile manufacturers and retail chains to make them at least partially responsible for compliance with minimum conditions of work and employment. ${ }^{6}$

Finally, the last type of regulation relates to more complex (supranational and transnational) governance structures in which international organizations such as the OECD interact with MNC, states, social partners, and NGOs. The OECD Multinational Guidelines regarding the behaviour of $\mathrm{MNC}$, which have either a global or a macro-regional effect depending on the company, are equipped with comparatively strong control resources, providing for complaint procedures and test procedures by the concerned states as well as public documentation of all procedures. International NGOs also organize critical independent monitoring of all complaints. ${ }^{7}$

These different types of transnational labour relations and aspects of the regulation of work, employment, and participation are traditionally viewed and treated separately, although they are all being discussed in the scientific discourse and also by the relevant collective and corporate actors such as governmental and professional bodies, trade unions, companies, and NGOs. For example, the experts at the National Contact Points for the OECD Guidelines deal with incoming complaints, because this is their area of responsibility. The international trade union confederations, like the GUF, often focus their activities on the conclusions of the IFA, which know and appreciate the collective bargaining instrument at the national level. International companies tend to focus on developing policies for responsible and sustainable management, sometimes also trying to implement appropriate monitoring, verification, and certification procedures. In contrast, NGOs are usually looking for especially serious cases of misconduct and specific issues in order to direct attention to them and achieve resolution through combined activities. As a result of such selective and isolated perceptions of cross-border labour regulation activities, the social and political options and opportunities in transnational labour

\footnotetext{
${ }^{5}$ See e.g. Scherrer and Greven 2001; Schäfer et al. 2006; ITUC (International Trade Union Confederation) 2008; Leipziger 2009; Kahn-Nisser 2014; Ramanan 2018; https://goodweave.org/; https://www.fairtradecertified.org/; https://www.globalreporting.org/Pages/default.aspx.

${ }^{6}$ See e.g. Ost 2002; Seidman 2007; Zajak 2016 and 2017; for the CCC, see e.g. https://cleanclothes.org/; for other campaigns see e.g. https://www.befair.be/en/content/business-social-compliance-initiative-bsci; http://www.ilo.org/ipec/Campaignandadvocacy/wdacl/lang\%2D\%2Den/index.htm.

${ }^{7}$ For the case of EWC and the governance of labour regulation in Europe in general see e.g. Marginson and Sisson 2006; Dehnen 2013; De Spiegelaere and Jagodzinski 2015; Hauser-Ditz et al. 2016; Hann et al. 2017; Pulignano 2017
} 
regulation have been underestimated. This obstacle might be akin to seeing many different trees but not the forest.

The development of the OECD Guidelines shows the potential scope and consequences of variations in their application and is not without irony. The initial attempt to pass a corresponding agreement, especially by liberal market forces, without engaging in a broader discussion ultimately (and unilaterally in the interests of large MNCs) had the opposite effect: after massive protests by national and transnational NGO groups, a new governance structure was created based on the participation of the four actor groups: state, enterprise, trade union, and NGO. Similar effects, known in sociology as the 'unanticipated consequences of purposeful social action' (Merton 1936), show up in other examples. Companies that wrote voluntary statements under the Global Compact, pursuing a strategy of nonbinding unilateral declarations and thus aiming to prevent more binding international recruitment regulations, suddenly found themselves confronted with their own stated claims of corporate responsibility (e.g. not applying mass dismissals) when they intended to close plants. The OECD guidelines provided trade unions and NGOs with the additional leverage of public pressure.

Precisely because the various types of transnational labour regulations are intertwined, one cannot properly analyse their functions and effects by looking at each mechanism separately. At the same time, the specific groups of actors generally have different emphases and approaches in international labour regulation. These differences can lead to an interest-driven 'tunnel vision,' by which one tends to perceive one's own activities as more positive and those of other actors as more of a problem. For example, trade unions and NGO groups criticize the voluntary corporate activities regarding international labour market regulation as being oriented toward fostering a perception of public legitimacy and risk management rather than toward truly sustainable corporate social responsibility. Conversely, international corporations complain that their opponents and critics do not take into account the complicated conditions of action and interest structures in the countries where such corporations operate production sites.

In view of the increasingly complex relations associated with globalization and the transnationalization of labour, it is tempting to slip into simplistic national patterns of thinking. And indeed, there are signs of a trend toward a renationalization of labour regulation (Stöss 2017). Therefore, neither globalization nor renationalization of labour regulation can be considered as clear and unambiguous trends. The transnationalization of labour regulation should be understood as an emergent and multifaceted trend. It includes multilevel and multidimensional mechanisms, action logics, and actor constellations. It is fragile and highly dependent on economic factors but also on political structures and social networks of collective actors (Yeung and Tung 1996). The experience of the Bangladesh Accord is an example of such complex intertwined logics of regulation.

\section{Discussion of example: the Bangladesh accord as successful transnational labour regulation}

On April 24, 2013 the so-called Rana Plaza collapse destroyed an eight-story garment factory building in the Dhaka District in Bangladesh. More than 1100 workers died, and some 2500 people were injured. The building covered many 
textile and clothing factories, but also apartments and other shops. Obvious cracks in the building had been observed in the days before the collapse, but the owners and employers did not pay attention to any warnings. Part of the building was constructed without permit, but the owners belonged to the local political establishment. Although several other severe accidents had occurred in the Bangladeshi garment industry, and despite strong international critique, no remediation had been undertaken so far. The Rana Plaza collapse could be taken as the tip of the iceberg of structural challenges of work and employment conditions in the country.

The textile and garment industry, especially the Ready Made Garment (RMG) sector, is one of the most important sectors of the Bangladeshi economy since the Multi Fiber Agreement of 1974 opened corresponding trade between countries of the North and the South. From that year on, the share of textiles out of all exports increased from zero to some $75 \%$ in 2005 , with export to the USA and Europe comprising almost nine tenth of that trade (Haider 2007: 3f). The boom continued even after the Multi Fiber Agreement in 2005 was replaced by the Agreement on Textiles and Clothing. Bangladesh is the second biggest producer of textiles and garment after China. This very quick expansion of the industry went hand in hand with improvised buildings, precarious labour conditions, and lack of state control. Several factories collapsed due to construction flaws. For instance, in 2005 the Spectrum garment factory collapsed, killing seventy-three workers. ${ }^{8}$ Against the traditional state and party controlled system of official unions, independent trade union organizations have developed since the start of the new century (Rock 2005). Traditionally, so-called basic trade unions, such as plant or factory unions, prevail; they are often directly connected with a political party. It was not until 2006 that the Bangladesh Labour Act allowed workers to unionize in independent organizations.

Nevertheless, according to the ILO (International Labour Organization) 2017: 3 ), less than $5 \%$ of the factories of the Bangladeshi RMG industry have a union presence. In contrast, non-governmental organizations (NGO) are of crucial significance in the country: "Bangladesh is reported to have more NGOs per capita than any other developing country ... with around 22,000 NGOs estimated to be in existence." (Kabeer et al. 2010: 7). The NGO structure in Bangladesh is highly dependent on international development aid, and it is highly centralized and homogeneous: "Of the 1250 NGOs that received international assistance in 1999-2000, 11 of the bigger NGOs received 85 per cent of all assistance to NGOs." (ibid: 13). As compared to trade unions, NGOs in Bangladesh seem to play a more significant role when it comes to collective action. "The socially oriented development NGOs (Samata, Nijera Kori, and BRAC) that were studied in rural areas were far more likely to promote such action than the trade unions and minimalist microfinance organisations that made up the urban sample." (ibid: 8). The exceptionally high significance of NGOs dedicated to fighting poverty and improving democratic civil participation is underlined and repeated in social movement and NGO literature on Bangladesh. In contrast, in the literature related to unions and labour regulation in

\footnotetext{
${ }^{8}$ See https://cleanclothes.org/news/2013/04/11/spectrum-collapse-eight-years-on-and-still-little-action-onsafety; for further collapses see https://en.wikipedia.org/wiki/2005_Dhaka_garment_factory_collapse.
} 
Bangladesh, the NGO presence is nearly absent. Before discussing details of the relation between unions and NGOs, we must first look at the history of the Bangladesh Accord.

The 2014 Rana Plaza collapse was the most globally visible and the deadliest accident to affect the international RMG industry. Nevertheless, it did not come by surprise. In the context of the very fast growth of the sector, the near absence of strong unions, a liberal and unconditional state policy of export industrialization, as well as a lax health and safety regime, there had been many tragedies due to buildings collapsing or burning. Only considering the latter, "on the basis of conservative estimates, the statistics regarding factory fires show that at least 1,000 garment workers have lost their lives and 3,000 workers have been injured in more than 275 incidents since 1990" (Fink 2014: 43). The Clean Cloth Campaign (CCC), founded in the Netherlands in 1989 and developed in the 1990s, created a Europewide network. "This Europe-wide network is in turn part of a larger international network of trade unions and labour NGO's, both in producing and consuming countries, which strives to advance workers' rights worldwide." (CCC (Clean Cloth Campaign) 2004: 3). The CCC reported regularly about work and employment conditions as well as accidents and injuries on work in the Bangladeshi RMG industry. ${ }^{9}$ The CCC cooperated with GUFs that are active in the garment industry, namely IndustriALL and UNI, the latter tried to negotiate and sign IFAs with the Bangladeshi RMG sector.

Though some of the RMG companies in Bangladesh had declared their CSR commitment and organized plant inspections - even in two of the factories that collapsed in Rana Plaza in March 2014 (Fink 2014: 46), it took the tragedy of Rana Plaza to prompt the signing of a substantial agreement. Prior to 2014 , “( . . . ) in 2012 within the framework of a multi-stakeholder initiative, a Memorandum of Understanding on fire prevention and building safety was worked out for Bangladesh ( ... ) This 2012 MOU served as the template for the negotiations on the accord after the Rana Plaza catastrophe" (Zimmer 2016: 3). The Bangladesh Accord defined as its goal the achievement of a safe and sustainable Bangladeshi RMG industry in which no worker needs to fear fires, building collapses, or other accidents. It included the formation of a Steering Committee composed by three representatives of trade unions and of companies each, plus one representative of the ILO. Additionally, it approved creation of an Advisory Board with representatives of international brands and retailers as customers of the Bangladeshi RMG industry, as well as suppliers, government institutions, trade unions, and NGOs. A complex system of Safety Inspectors was defined, and inspections and reports were scheduled for first, second, and third tier suppliers. The accord defined that from the very beginning, all inspection reports and other relevant documents were to be published electronically. ${ }^{10}$

Meanwhile, there exist many scientific studies and reports on the accord and its practical working and effects. In general, the accord can be considered an example of a multilevel and multidimensional institutionalized mechanism of transnational

\footnotetext{
${ }^{9}$ See e.g. https://cleanclothes.org/@ @ search?SearchableText=bangladesh.

${ }^{10}$ See https://bangladeshaccord.org/
} 
labour regulation. First, it includes a wider range of stakeholders, as it was signed by producers and retailers, by trade unions, the ILO, and by NGOs as 'attesters' of the agreement. Meanwhile, in 2019 it was signed by 194 companies from 22 countries, by the GUFs IndustriALL and UNI Global Union and by eight Bangladeshi affiliates of IndustriALL. Four international NGOs (CCC, International Labor Rights Forum, Maquila Solidarity Network, and Worker Rights Consortium) were the 'witness signatories.' In addition, 1580 accords with factories in Bangladesh always include transparent documentation of inspections, observations, and action plans with time schedules, etc. (see Table 2). Meanwhile, some 35,000 initial and follow-up inspections have been documented. It is noteworthy that, by signing the accord, important brand-name companies from almost all over the world accepted responsibility for work and employment conditions in the factories of their suppliers.

Second, besides the actors directly involved by the accord and its subsequent accords with supplier companies, the accord introduced the logic of transparency and legitimation in an emerging and institutionalizing 'organizational field' of "Fire and Building Safety in Bangladesh". "In a neo-institutionalist approach, there are many elements of all three types of legitimation. Legal mechanisms of legitimation are introduced for conflict resolution:

Conflicts between the signatory parties are to be mediated first and foremost by the steering committee, which is supposed to make a decision within 21 days at the most by a simple majority (par. 5). If the dispute cannot be resolved at this level the next step is to appoint a court of arbitration, that functions in accordance with the UNCITRAL regulations for international commercial arbitration and whose arbitration award is legally enforceable in accordance with the New York Convention in the country of the headquarter of the relevant signatory company (Zimmer 2016: 5).

Professional mechanisms were mainly installed by the system of factory inspectors and their standardized tools. Finally, cognitive mechanisms of legitimation work by the increasingly taken-for-granted scheme of inspections, transparency and 'Corrective Action Plans.' Scientific research on the effect of the accord underlines the high degree of transparency and public documentation of all steps: "The high degree of transparency is particularly noteworthy; for example, not only the supplier firms, but also all inspection reports and remediation plans are accessible online" (ibid: 4).

Third, the Bangladesh Accord had sustainable effects on the supply chain as well as on the political system of the country. The large number of companies involved, step by step, in the factory inspection system made the commitment to fire and building safety trickle down from the national to the local level. At the same time, based on the disaster at Rana Plaza and the following multi-stakeholder Accord, the Bangladeshi government passed a National Action Plan for safety at work

\footnotetext{
${ }^{11}$ For the neo-institutionalist approach of the regulative, normative and cognitive pillar of legitimation in organizational fields see e.g. Scott 1995.
} 
Table 2 Example of "Corrective Action Plan" (CAP for ABM Fashions Limited)

\begin{tabular}{|c|c|c|c|c|c|c|c|}
\hline \multicolumn{2}{|c|}{ 14-Jul-2019 } & \multicolumn{6}{|c|}{ STRUCTURAL \& BUILDING SAFETY } \\
\hline & & \multicolumn{6}{|c|}{ Bangladesh Accord Remediation Summary of Actions Required } \\
\hline & Factory Name \& Address & \multicolumn{6}{|c|}{ ABM Fashions Ltd, 1143 \& 1145, Konabari, Kashimpur Road, Gazipur., Gazipur, Dhaka } \\
\hline & Date of Inspection by Accord & \multirow{2}{*}{\multicolumn{6}{|c|}{$27-0 \mathrm{kt}-2015$}} \\
\hline & Accord Rating & & & & & & \\
\hline & Finance Plan Agreed & \multicolumn{6}{|c|}{ Yes } \\
\hline $\begin{array}{c}\text { Item } \\
\text { No }\end{array}$ & Accord Inspection Observation & Accord Action Plan & Final Action Plan & $\begin{array}{l}\text { Final } \\
\text { Timeline }\end{array}$ & Comments from Accord & $\begin{array}{l}\text { Accord } \\
\text { Timeline }\end{array}$ & $\begin{array}{c}\text { Progress } \\
\text { Status }\end{array}$ \\
\hline 1 & $\begin{array}{l}\text { Column on grid P-6 appears to be } \\
\text { critically stressed both in capacity and } \\
\text { punching shear. Verify concrete } \\
\text { strength in columns }\end{array}$ & $\begin{array}{l}\text { Do not carry out any further fit out } \\
\text { works in the toilets in the area of } \\
\text { column P6 until design check has been } \\
\text { carried out. }\end{array}$ & $\begin{array}{l}\text { Corrected } \\
\text { DEA documents have been reviewed } \\
\text { and accepted by ACCORD On 24th May } \\
\text { 2017. As per recommendation of DEA } \\
\text { dismantling works completed in } \\
\text { column on grid P-6. }\end{array}$ & $01 / 07 / 2016$ & $\begin{array}{l}\text { On 09/05/2016: Factory } \\
\text { managements intention is to carry } \\
\text { out a Detail Engineering Assessment } \\
\text { (DEA). For completation of DEA, } \\
\text { factory management have already } \\
\text { appointed an consultant and } \\
\text { working on DEA. This issue requires }\end{array}$ & e-Now) & Corrected \\
\hline 2 & $\begin{array}{l}\text { Column on grid P-6 appears to be } \\
\text { critically stressed both in capacity and } \\
\text { punching shear. Verify concrete } \\
\text { strength in columns }\end{array}$ & $\begin{array}{l}\text { Factory Engineer to carry out a } \\
\text { detailed check on the loading and } \\
\text { actual capacity of column on grid P6. } \\
\text { A check is to be carried out on site to } \\
\text { ascertain if shear reinforcement has } \\
\text { been provided in the slab at the } \\
\text { column head. }\end{array}$ & $\begin{array}{l}\text { Corrected DEA } \\
\text { documents have been reviewed and } \\
\text { accepted by ACCORD On 24th May } \\
2017 .\end{array}$ & $01 / 07 / 2016$ & $\begin{array}{l}\text { On 09/05/2016: Factory } \\
\text { managements intention is to carry } \\
\text { out a Detail Engineering Assessment } \\
\text { (DEA). For complete of DEA, factory } \\
\text { management have already } \\
\text { appointed an consultant and } \\
\text { working on issue requires to cover }\end{array}$ & $\begin{array}{l}\text { (within 6- } \\
\text { weeks) }\end{array}$ & Corrected \\
\hline 3 & $\begin{array}{l}\text { Column on grid } P-6 \text { appears to be } \\
\text { critically stressed both in capacity and } \\
\text { punching shear. Verify concrete } \\
\text { strength in columns }\end{array}$ & $\begin{array}{l}\text { Verify insituconcrete strengths either } \\
\text { by } 100 \mathrm{~mm} \text { diameter cores or existing } \\
\text { cylinder strength data for column P-6. }\end{array}$ & $\begin{array}{l}\text { Corrected } \\
\text { total of } 08 \text { nos core cutting done and } \\
\text { test result found satisfactory and DEA } \\
\text { done as per core test report.DEA } \\
\text { documents have been reviewed and } \\
\text { accepted by ACCORD On 24th May } \\
2017 \text {. }\end{array}$ & $01 / 07 / 2016$ & $\begin{array}{l}\text { On 09/05/2016: Core cutting in } \\
\text { columns at several places have } \\
\text { observed. However in core test } \\
\text { result it is mention that, client of } \\
\text { core test report is Mr.Salahuddin } \\
\text { Ahmed,Compliance Manager, } \\
\text { Meditex Knitwear Ltd, Mirpur, }\end{array}$ & $\begin{array}{l}\text { (within 6- } \\
\text { weeks) }\end{array}$ & Corrected \\
\hline 4 & $\begin{array}{l}\text { Column on grid P-6 appears to be } \\
\text { critically stressed both in capacity and } \\
\text { punching shear. Verify concrete } \\
\text { strength in columns }\end{array}$ & $\begin{array}{l}\text { Make structural alterations if required } \\
\text { as advised by Factory Engineer }\end{array}$ & $\begin{array}{l}\text { Corrected } \\
\text { DEA documents have been reviewed } \\
\text { and accepted by ACCORD On 24th May } \\
\text { 2017. As per recommendation of DEA } \\
\text { dismantling works completed in } \\
\text { column on grid P-6. }\end{array}$ & $01 / 07 / 2016$ & $\begin{array}{l}\text { On 09/05/2016: Factory } \\
\text { managements intention is to carry } \\
\text { out a Detail Engineering Assessment } \\
\text { (DEA). For completation of DEA, } \\
\text { factory management have already } \\
\text { appointed an consultant and } \\
\text { working on issue requires to cover }\end{array}$ & $\begin{array}{l}\text { (within 6- } \\
\text { months) }\end{array}$ & Corrected \\
\hline 5 & $\begin{array}{l}\text { Discrepancies between drawings and } \\
\text { as built structure. Possible punching } \\
\text { shear problem on edge and central } \\
\text { columns. }\end{array}$ & $\begin{array}{l}\text { Factory Engineer to check on site if } \\
\text { shear reinforcement has been put into } \\
\text { the slab at column heads both at the } \\
\text { perimeter and the middle of the slab. }\end{array}$ & $\begin{array}{l}\text { Corrected DEA } \\
\text { documents have been reviewed and } \\
\text { accepted by ACCORD On 24th May } \\
2017 \text {. }\end{array}$ & $01 / 07 / 2016$ & $\begin{array}{l}\text { On 09/05/2016: Factory } \\
\text { managements intention is to carry } \\
\text { out a Detail Engineering Assessment } \\
\text { (DEA). For completation of DEA, } \\
\text { factory management have already } \\
\text { appointed an consultant and } \\
\text { working on issue requires to cover }\end{array}$ & $t^{\substack{\text { Immediate } \\
\text { Now }}}$ & Corrected \\
\hline 6 & $\begin{array}{l}\text { Discrepancies between drawings and } \\
\text { as built structure. Possible punching } \\
\text { shear problem on edge and central } \\
\text { columns. }\end{array}$ & $\begin{array}{l}\text { Make any structural alterations as } \\
\text { advised by Factory Engineer. }\end{array}$ & $\begin{array}{l}\text { Corrected DEA } \\
\text { documents have been reviewed and } \\
\text { accepted by ACCORD On 24th May } \\
2017 \text {. }\end{array}$ & $01 / 07 / 2016$ & $\begin{array}{l}\text { On 09/05/2016: Factory } \\
\text { managements intention is to carry } \\
\text { out a Detail Engineering Assessment } \\
\text { (DEA). For completation of DEA, } \\
\text { factory management have already } \\
\text { appointed an consultant and }\end{array}$ & 6-weeks & Corrected \\
\hline 7 & $\begin{array}{l}\text { Discrepancies between drawings and } \\
\text { as built structure. Possible punching } \\
\text { shear problem on edge and central } \\
\text { columns. }\end{array}$ & $\begin{array}{l}\text { Factory Engineer to fully compare the } \\
\text { building drawings with the as-built } \\
\text { structure. }\end{array}$ & $\begin{array}{l}\text { Corrected DEA } \\
\text { documents have been reviewed and } \\
\text { accepted by ACCORD On 24th May } \\
2017 \text {. }\end{array}$ & $01 / 07 / 2016$ & $\begin{array}{l}\text { On 09/05/2016: Factory } \\
\text { managements intention is to carry } \\
\text { out a Detail Engineering Assessment } \\
\text { (DEA). For completation of DEA, } \\
\text { factory management have already } \\
\text { appointed an consultant and } \\
\text { working on issue requires to cover }\end{array}$ & 6-weeks & Corrected \\
\hline 8 & $\begin{array}{l}\text { Discrepancies between drawings and } \\
\text { as built structure. Possible punching } \\
\text { shear problem on edge and central } \\
\text { columns. }\end{array}$ & $\begin{array}{l}\text { Update drawings to fully record the as- } \\
\text { built condition of the building. }\end{array}$ & $\begin{array}{l}\text { DEA } \\
\text { - Corrected } \\
\text { documents have been reviewed and } \\
\text { accepted by ACCORD On 24th May } \\
2017 \text {. }\end{array}$ & $01 / 07 / 2016$ & $\begin{array}{l}\text { On 09/05/2016: Factory } \\
\text { managements intention is to carry } \\
\text { out a Detail Engineering Assessment } \\
\text { (DEA). For completation of DEA, } \\
\text { factory management have already } \\
\text { appointed an consultant and } \\
\text { working on issue requires to cover }\end{array}$ & 6-months & Corrected \\
\hline ǵ & $\begin{array}{l}\text { Actively manage and implement } \\
\text { existing load plan. }\end{array}$ & $\begin{array}{l}\text { Factory Engineer to review loads on } \\
\text { floor areas. }\end{array}$ & $\begin{array}{l}\text { Corrected DEA } \\
\text { documents have been reviewed and } \\
\text { accepted by ACCORD On 24th May } \\
2017 \text { \& Load Plan implemented as per } \\
\text { Accord recommendation. }\end{array}$ & $01 / 07 / 2016$ & $\begin{array}{l}\text { On 09/05/2016: Before approval of } \\
\text { DEA factory requires to maintain } \\
\text { loading below } 42 \text { existing loading } \\
\text { plan was observed in floors and } \\
\text { loading was found below } 42 \text { psf } \\
\text { except some areas of } 1 \text { st and } 2 \text { nd } \\
\text { floors. After approval of DEA from }\end{array}$ & 6-weeks & Corrected \\
\hline 10 & $\begin{array}{l}\text { Actively manage and implement } \\
\text { existing load plan. }\end{array}$ & $\begin{array}{l}\text { Actively manage existing loading plan } \\
\text { for all floor plates within all buildings, } \\
\text { giving consideration to floor capacity } \\
\text { and column capacity. }\end{array}$ & $\begin{array}{l}\text { Corrected DEA } \\
\text { documents have been reviewed and } \\
\text { accepted by ACCORD On 24th May } \\
2017 \text { \& Load Plan implemented as per } \\
\text { Accord recommendation. }\end{array}$ & $31 / 07 / 2016$ & $\begin{array}{l}\text { On 09/05/2016: Before approval of } \\
\text { DEA factory requires to maintain } \\
\text { loading below } 42 \text { psf. However } \\
\text { existing loading plan was observed } \\
\text { in floors and loading was found } \\
\text { below } 42 \text { psf except some areas of } \\
1 \text { st and } 2 \text { nd floors. After approval of }\end{array}$ & $\begin{array}{l}6 \text {-weeks } \\
\text { f }\end{array}$ & Corrected \\
\hline
\end{tabular}

Source: https://bangladeshaccord.org/factories.

and the reformed National Labour Act of July 2013, including legal provisions that already were proposed by the ILO in 2012. These national legal provisions strengthened the factory inspection system and workers' rights of free union association and of collective bargaining.

In sum, the Bangladesh Accord could be considered an innovative arrangement of transnational labour regulation. A great part of this success can be explained by combining and interweaving the different labour mechanisms outlined in section 1 
(Table 1). The ILO was an important actor for strengthening ideas of minimum standards and core convention provisions like freedom of union association and collective bargaining. By establishing a bipartite Steering Committee with an ILO representative as neutral chair, a supranational labour regulation body was installed. The strong role of two GUFs and of many strong global retail chain companies took up elements of IFA regulation mechanisms and of CSR declarations, but the accord went far beyond these types of regulations by setting up legally binding mechanisms of conflict resolution. CCC and other NGOs signed the accord not as equal parts but as witnesses of the treaty. Nevertheless, in combination with factory inspections and the high level of transparency, strong elements of labelling, monitoring and certifying as well as of public campaigning are in play. Finally, the accord set the ground for a transnational governance regime in the arena of safety at work. ${ }^{12}$

Despite these elements of an emerging transnational labour regulation regime, there remain many limitations and questions. Although the accord trickled down through the RMG sector, strong limitations arose e.g. from the competition and tensions between unions and NGOs as crucial actors to ground the accord in society and economy:

In view of the absence of labour unions on the factory level, this vacuum has been partially filled by internationally funded NGOs that offer training on various issues and also provide basic services such as health care and childcare. Although these services are much needed and are generally welcomed by workers, NGOs' increased activity in the RMG industry is also viewed sceptically. Trade unionists particularly criticize their lack of commitment, a supposedly de-politicized stance and, most importantly, the additional barriers against organizing that are seen to evolve due to NGOs' involvement. Thus, far from detecting a 'social-movement unionism' ... with a few exceptions, the relationship between the two actors tends to be competitive and adversarial (Fink 2014: 46).

The still fragile arrangement of the accord is also reflected in the resistance of the Bangladeshi government when it came to signing a follow up agreement in 2018. Based on the accord inspection mechanisms the contracts for some 500 suppliers were to be rejected given that they did not improve their fire and building safety. Therefore, the government argued that such an intervention was too much and that the country itself and its "Remediation and Coordination Cell" (RCC) were able to control and regulate the problematic cases. Accord actors argued that about 100 independent inspectors were doing some 500 factory inspections each month, meanwhile RCC inspectors only worked on a third of that volume. The High Court postponed a final decision in December 2018, and in April 2019 the accord seemed to be finished. Finally, in May 2019 a Memorandum of Understanding, accepted by the High Court, the government, and the accord actors, ruled that from spring

\footnotetext{
${ }^{12}$ By this, and contrary to the main arguments in Reinecke and Donaghey 2015, on the one hand, it goes far beyond intersecting the production-consumption line, but, on the other hand, direct pressure of involvement by consumer organizations was weak.
} 
2020 onwards a state governed "RMG Sustainability Council" should continue the work of the accord. Unions and NGOs were sceptical and they criticized the strengthening of employers' associations under the new governance system. ${ }^{13}$ The future will show if substantial elements of the transnational labour regulation logic can be continued in the now 'renationalized' system.

\section{Conclusion: towards an approach of transnational labour regulation}

The example of the Bangladesh Accord underlines the need to broaden our concepts of labour regulation. Against 'methodological nationalism' and concepts of analysing labour regulation exclusively in the containers of national societies, the accord reveals how big retail chains, trade unions, and NGOs could jointly work across borders in order to improve the safety needs of workers in countries thousands of kilometres away. Nevertheless, against 'methodological globalism' the example also underlines that there is no easy and unilinear way towards a cosmopolitan order and globalising institutions. Neither economic determinism nor activist voluntarism will adequately explain the dynamics before, during and after the Bangladesh Accord. The example suggests an integrative perspective on sewing transnational textures of labour regulation in a multilevel and multi-stakeholder setting. Neoinstitutionalism orients to focus on the emerging 'organizational field' where new regulative, normative and cognitive pillars could strengthen an institutionalised regime of norms and practices of fire and building safety. As could be seen in the National Labour Act of 2013, such a limited field of regulation could be the nucleus of further arenas of labour regulation.

In the twenty-first century, class and nation are too narrow concepts for analysing labour regulation. The spatial reach of regulation could be local, regional, national, supranational, transnational or global. For the case of the textile and garment industry, global value chains require a global and transnational approach. Customers are increasingly sensitive and aware of the ecological and working conditions of the production of consumer goods. Corresponding civil society organisations and NGOs span channels of communication around the world. The Bangladesh Accord reveals how the local (factories, unions and NGOs), the national (sector, associations, and government), the transnational (networks of retailers, GUFs and NGOs), and the global level (ILO minimum standards of decent work) are interacting (Tighe 2016).

We also recognize that the modes of regulation and type of conflicts have differentiated since the growth of modern capitalism and dependent work. Thus, we analyse the formal and informal modes of conflict and conflict regulation. Also, we differentiate between substantial and procedural logics of regulation. In the case of the Bangladesh Accord, however, we also have to figure out the conflict and

\footnotetext{
${ }^{13}$ See e.g. https://cleanclothes.org/news/2019/04/02/government-of-bangladesh-not-ready-to-take-overaccord2019s-safety-work; https://cleanclothes.org/news/2019/05/21/questions-raised-after-agreementreached-on-bangladesh-accord; more positively http://www.industriall-union.org/bangladesh-accordachievements-secured
} 
regulation between consumption and production interests. There exists also a wide scope of needs negotiated in the conflict that ranges between the basic needs of security at work for production workers and the social and ecological consciousness of consumers. If the latter cannot be mobilised, there will be little leverage for influencing the former. Also the mode of regulation is much more complicated than the classic forms of negotiating collective bargaining agreements and creating new laws. The accord set the ground for new ways of norm generation, norm interpretation, and norm implementation by a system of inspections, inspection reports, their transparent global availability and thus exerting the pressure of legitimation.

Furthermore, the dominant actor groups go far beyond unions, employer associations, companies, shop stewards, works councils, and officials of international organisations. Transnational NGOs of different value orientations and with different agendas, as well as social issue networks, consumer groups, and transnational professional groups (e.g. of CSR or sustainable development experts) have substantially influenced the dynamics and outcome of the accord. Thereby, the prevailing sources of power included social capital (as social relations of trust), cultural capital (as knowledge and skills), economic capital (as financial resources), organizational capital (as membership and experts), and political capital (as degrees of influence in political parties and governments).

All these aspects could be integrated in an institutionalist approach. According to this, the world of economy and society, of labour and its regulation is structured by social institutions. Institutions are understood as inherited action programs (laws/ rules, norms, cognitive maps) that structure certain areas of social life and extended social groups, and that could extend at local, national, supranational, global or transnational levels that emerge and stabilize by habitualizing, making explicit, typifying, and formalizing, and that give social identity, stability, integration and predictability. For more than the last hundred years, the dominant paradigms in the social sciences start by taking markets and states for granted, considering them the most important institutions (Hyman 2008; Hall and Soskice 2001). But by the mid twentieth century, dual labour-market theories and then organization theory underlined the impact of companies as complex arrangements based on the division of labour and allowed for the developing of specific internal rules of gratification, training, work place mobility and culture (Kerr 1954; Acker 1990). For many European countries, especially Germany, labour market research demonstrated the overarching role of professions, of craftsmanship, and of technicians for structuring economy, work, and employment relations (Maurice et al. 1980; Abbott 2005). Later on, social networks 'between markets and hierarchies,' as crucial institutions, were focused based on mutual trust and unspecific reciprocity (Bourdieu 1986; Coleman 1988).

Taking the examples presented in section 1 and the case of the Bangladesh Accord, all these general social institutions (states, markets, organisations, professionalism, and social networks) are in play. In a neo-institutionalist perspective, we analyse the behaviour of organisations as collective actors in their institutionalised environments in more detail. For the case of the accord, we can demonstrate that all collective actors (companies, unions, NGOs, social movement groups, public and state agencies, etc.) orient themselves to not only organisation-related rational goals but also to perceived expectations of legitimacy in their institutional environment. 
According to neo-institutionalism, these institutional environments are composed by coercive, normative and mimetic mechanisms. We can prove the momentum of all three "pillars of institutions" (Scott 2001: 35) in the Bangladesh Accord. Although neo-institutionalism assumes long-term stability of institutions once they are settled and embedded by their three pillars, it is not a deterministic approach. The example of the accord underlines that institutionalising of fire and building safety in Bangladesh is still an open and fragile process.

\section{Publisher's Note}

Springer Nature remains neutral with regard to jurisdictional claims in published maps and institutional affiliations.

\section{Acknowledgements Not applicable.}

\section{Author's contributions}

The author is the only contributor to this paper.

\section{Authors' information}

Not applicable.

Dataset

The data for this paper consist, first, of primary data collected by the authors based on case studies and expert interviews in different industries, these sources are cited in the paper as:

Dehnen and Pries (2014) International Framework Agreements as a thread in the texture of transnational labour regulation. European Journal of Industrial Relations 20(4): 335-350.

Hauser-Ditz et al. (2016) A Solution for Transnational Labour Regulation? Company Internationalization and European Works Councils in the Automotive Sector. New York, Bern, Berlin, Bruxelles, Frankfurt am Main, Oxford, Wien: Peter Lang.

Hertwig et al. (2010) European Works Councils in complementary perspectives. Brussels: ETUI.

The second data source is secondary data analysis of published reports that are made available in the context of the Bangladesh Accord. All sources used are cited in the article correspondingly.

\section{Funding}

There was no specific funding for this paper.

\section{Availability of data and materials}

Not applicable. 


\section{Ethics approval and consent to participate}

Approved hereby.

\section{Consent for publication}

Given hereby.

\section{Competing interests}

No competing interests.

\section{References}

Abbott, Andrew. 2005. Sociology of work and occupations. In The handbook of economic sociology, ed. Neil Smelser and Richard Swedberg, 2nd ed., 307-330. Princeton: Princeton University Press.

Acker, Joan. 1990. Hierarchies, jobs, bodies: A theory of gendered organizations. Gender \& Society 4 (2): 139-158.

Alston, Philip. 2004. 'Core labour standards' and the transformation of the international labour rights regime. European Journal of International Law 15: 457-521.

Bakvis, Peter, and Molly McCoy. 2008. Core labour standards and international organizations: What inroads has labour made? Bonn: Friedrich-Ebert-Stiftung.

Besio, Christina, and Uli Meyer. 2015. Heterogeneity in world society: How organizations handle contradicting logics. In From globalization to world society: Neo-institutional and systems-theoretical perspectives, ed. Boris Holzer, Fatima Kastner, and Tobias Werron, 237-257. New York: Routledge.

Bourdieu, Pierre. 1986. The forms of capital. In Handbook of theory and research for the sociology of education, ed. John G. Richardson, 241-258. London: Greenwood Press.

Bugra, Alyse, and Kaan Agartan. 2007. Reading Karl Polanyi for the twenty first century. In Market economy as a political project. New York: Palgrave.

Burawoy, Michael. 2010. From Polanyi to Pollyanna: The false optimism of global labour studies. Global Labour Journal 1 (2): 301-313.

CCC (Clean Cloth Campaign). 2004. Annual report 2004. Amsterdam: CCC download: https://cleanclothes. org/about/annual-reports/annual-2004.pdf/view. Accessed 24 Apr 2020.

Coleman, James. 1988. Social Capital in the Creation of human capital. American Journal of Sociology 94 : 95-120.

Croucher, Richard, and Elizabeth Cotton. 2009. Global unions, global business. In Global union federations and international business. London: Middlesex University Press.

De Spiegelaere, Stan, and Romuald Jagodzinski. 2015. European Works Councils and SE Works Councils in 2015. Facts \& figures. Brussels: ETUI.

Dehnen, Veronika. 2013. Transnational alliances for negotiating international framework agreements: Power relations and bargaining processes between global union federations and European works councils. British Journal of Industrial Relations 51 (3): 577-600.

Dehnen, Veronika, and Ludger Pries. 2014. International framework agreements as a thread in the texture of transnational labour regulation. European Journal of Industrial Relations 20 (4): 335-350.

Dombois, Ranier, Ernhard Hornberger, and Jens Winter. 2003. Transnational labour regulation in the NAFTA - A problem of institutional design? The case of the north American agreement on labour cooperation between the USA, Mexico and Canada. International Journal of Comparative Labour Law and Industrial Relations 19 (4): 421-440.

Fink, Elisabeth. 2014. Trade unions, NGOs, and Transnationalization: Experiences from the ready-made garment sector in Bangladesh. Asien. The German Journal on Contemporary Asia 130: 42-59. 
Hadwiger, Felix. 2015. "Global framework agreements: Achieving decent work in global supply chains." background paper. Geneva: ILO.

Hall, Peter, and David Soskice. 2001. Varieties of capitalism: The institutional foundations of comparative advantage. Oxford: Oxford University Press.

Hann, Deborah, Marco Hauptmeier, and Jeremy Waddington. 2017. European works councils after two decades. European Journal Industrial Relations 23 (3): 209-224.

Hassel, Anke. 2008. The evolution of a global labor governance regime. Governance: An International Journal of Policy, Administration, and Institutions 21 (2): 231-251.

Hauser-Ditz, Axel, Markus Hertwig, Ludger Pries, and Luitpold Rampeltshammer. 2016. A solution for transnational labour regulation? Company internationalization and European works councils in the automotive sector. Berlin: Peter Lang.

Hertwig, Markus, Ludger Pries, and Luitpold Rampeltshammer, eds. 2010. European works councils in complementary perspectives. Brussels: ETUI.

Hyman, Richard. 2008. The state in industrial relations. In The SAGE Handbook of Industrial Relations, edited by Paul Blyton, Nicolas bacon, Jack Fiorito, ed. E. Edmund Heery, 258-284. London: Sage.

ILO (International Labour Office). 2001. Report III (part 1B) third item on the agenda: Information and reports on the application of conventions and recommendations. Geneva: ILO.

ILO (International Labour Office). 2009. Rules of the Game. A Brief Introduction to International Labour Standards. Revised edition 2009. Geneva: ILO.

ILO (International Labour Organization). 2017. Trade unions in Bangladesh: Promoting safe and healthy workplaces in the ready made garment $(R M G)$ sector. Geneva: ILO.

ITUC (International Trade Union Confederation). 2008. A trade union guide to the GRI sustainability reporting guidelines. Brussels: ITUC.

Kabeer, Naila, Sameen Mahmud, and Jairo Guillermo Isaza Castro. 2010. "NGOs' strategies and the challenge of development and democracy in Bangladesh." IDS working paper 343. Sussex: University of Sussex.

Kahn-Nisser, Sara. 2014. External governance, convention ratification and monitoring: The EU, the ILO and labour standards in EU accession countries. European Journal of Industrial Relations 20 (4): 383-398.

Kerr, Clark. 1954. The balkanization of labor markets. In Labor mobility and economic opportunity, ed. E. W. Bakke et al., 92-110. Cambridge: Harvard University Press.

Lawrence, Thomas, and Roy Suddaby. 2006. Institutions and institutional work. In The SAGE handbook of organization studies, ed. Stewart Clegg, Cynthia Hardy, Thomas Lawrence, and Walter Nord, 2nd ed., 215-254. London: Sage.

Leipziger, Deborah, ed. 2009. SA8000: The first decade. Implementation, influence and impact. Sheffield: Greenleaf.

Marginson, Paul, and Keith Sisson. 2006. European integration and industrial relations. In Multi-level governance in the making. Basingstoke: Palgrave-Macmillan.

Maurice, Marc, Arndt Sorge, and Malcom Warner. 1980. Societal differences in organizing manufacturing units. A comparison of France, West Germany and Great Britain. Organisation Studies 1 (1): 59-86.

Meardi, Guglielmo. 2004. Short circuits in multinational companies: The extension of European works councils to Poland. European Journal of Industrial Relations 10 (2): 161-178.

Merton, Robert. 1936. The unanticipated consequences of purposive social action. American Sociological Review 1 (6): 894-904.

Meyer, John, John Boli, George Thomas, and Francisco Ramirez. 1997. World society and the nation-state. American Journal of Sociology 103 (1): 144-181.

Haider, Mohammed. 2007. Competitiveness of the Bangladesh ready-made garment industry in major international markets. Asia-Pacific Trade And Investment Review 3 (1): 3-29.

Müller, Torsten, Hans-Wolfgang Platzer, and Stefan Rüb. 2008. "International framework agreements - Opportunities and limitations of a new tool of global trade union policy." Briefing Papers No. 8. Bonn: Friedrich-Ebert-Stiftung.

Ost, David. 2002. The weakness of strong social movements: Models of unionism in the east European context. European Journal of Industrial Relations 8 (1): 33-51.

Pulignano, Valeria. 2017. Articulation within (and across) transnational workplaces and the role of European works councils. European Journal of Industrial Relations 23 (3): 261-276.

Ramanan, Raghavan. 2018. Introduction to sustainability analytics. London: Taylor \& Francis.

Reinecke, Juliana, and Jimmy Donaghey. 2015. After Rana plaza: Building coalitional power for labour rights between unions and (consumption-based) social movement organisations. Organization 22 (5): 720-740.

Reynaud, Emmanual. 2018. "The International Labour Organization and globalization: Fundamental rights, decent work and social justice." ILO Research Paper No. 21. Geneva: ILO. 
Riisgaard, Lone. 2005. International framework agreements: A new model for securing workers rights? Industrial Relations 44 (4): 707-737.

Rock, Marilyn. 2005. The rise of Bangladesh independent garment-workers' union (BIGU). In Organising labour in globalising Asia, ed. Jane Hutchinson and Andrew Brown, 27-47. London: Routledge.

Schäfer, Henry, Jana Beer, Jan Zenker, and Pedro Fernandes. 2006. Who is who in corporate social responsibility rating? A survey of internationally established rating systems that measure corporate responsibility. Gütersloh: BertelsmanStiftung.

Scherrer, Christoph, and Thomas Greven. 2001. Global rules for trade: Codes of conduct, social labeling, Worker's rights clauses. Münster: Westfälisches Dampfboot.

Scott, W. Richard. 2001. Institutions and organizations: Ideas, interests, and identities. Thousand Oaks: SAGE.

Seidman, Gay. 2007. Beyond the boycott: Labour rights, human rights, and transnational activism. New York: Russel Sage Foundation.

Stöss, Richard. 2017. Trade unions and right-wing extremism in Europe. Berlin: Friedrich-Ebert-Stiftung.

Tighe, Eleanor. 2014. Stakeholder capitalism and workers' rights in the Bangladesh garment industry $\mathrm{PhD}$ diss. University of Southampton/United Kingdom. University of Southampton Institutional Repository. https://eprints.soton.ac.uk/377151/.

Tighe, Eleanor. 2016. Voluntary governance in clothing production networks: Management perspectives on multi-stakeholder initiatives in Dhaka. Environment and Planning A 48 (12): 2504-2524.

Tsogas, George. 2009. International labour regulation: What have we really learnt so far? Industrial Relations 64 (1): 75-94.

Wimmer, Andreas, and Nina Glick Schiller. 2002. Methodological nationalism and beyond: Nation-state building, migration and the social sciences. Global Networks 2 (4): 301-334.

Yeung, Irene, and Rosalie Tung. 1996. Achieving business success in Confucian societies: The importance of guanxi (connections). Organizational Dynamics 25 (2): 54-65.

Zajak, Sabrina. 2016. Rethinking pathways of transnational activism. Global Society 31 (1): 125-143.

Zajak, Sabrina. 2017. Transnational activism, global labour governance, and China. New York: PalgraveMacmillan.

Zimmer, Reingard. 2016. Corporate responsibility in the "Bangladesh accord": Which regulations are transferable to other supply chains? Bonn: Friedrich Ebert Foundation. 